\title{
JUURNAL.RU
}

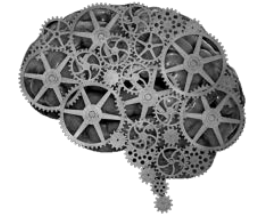

COMPANY GROUP "INTELLEKT"

Колесников В.Н., Бойко Н.В. Ростовский государственный медииинский университет

Ростов-на-Дону, Россия

doi: 10.18411/lj2016-3-16

\section{Диагностика атрофического ринита}

Атрофический ринит (АР) - упорно текущее заболевание, протекающее в двух формах - первичный и вторичный АР. Под первичным подразумевают АР, развивающийся как самостоятельное заболевание (озена), под вторичным атрофические изменения в полости носа, возникающие в результате травмы (в том числе, хирургической), гранулематозных заболеваний, инфекций, лучевых поражений и прочих повреждающих факторов.

Наиболее частой причиной возникновения вторичного АР являются хирургические вмешательства в полости носа с субтотальной резекцией или удалением носовых раковин, приводящие к формированию «синдрома пустого носа» [1].

Целью нашего исследования было изучение дыхательной функции носа у больных с атрофическим ринитом и ее изменений после физической нагрузки (ФН). Этот метод позволяет объективно характеризовать дыхательную функцию носа и широко используется в современной ринологии $[2,3,4]$.

Материал и методы исследования. Мы исследовали 30 больных в возрасте от 26 до 53 лет с вторичным АР, возникшим в результате многократных хирургических вмешательств в полости носа. Контрольную группу составили 30 здоровых испытуемых с нормальным носовым дыханием. 
Дыхательную функцию носа исследовали методом передней активной риноманометрии (ПАРМ). ПАРМ проводили на компьютерном риноманометре Rhinomanometer 200 (ATMOS).

Для оценки реактивности сосудистой системы слизистой оболочки носа использовали пробу с ФН. В качестве теста ФН мы избрали стандартный тредмил-тест с использованием протокола Брюса, который считается «золотым стандартом» проб с ФН.

Для определения влияния ФН на носовое дыхание проводился анализ изменения кривых ПАРМ, а также сравнение суммарного объемного потока (СОП) и суммарного сопротивления (СС) до и после ФН. Анализ проводился как в абсолютных, так и в относительных цифрах, для чего рассчитывали значения увеличения (уменьшения) каждого показателя, составляли из этих цифр вариационные ряды и обрабатывали их статистическими методами.

Результаты и их обсуждение. При проведении анализа результатов ПАРМ у больных АР обращает на себя внимание расхождение между оценкой пациентами качества своего носового дыхания и показателями ПАРМ.

Исходное значение СОП составило 1040,0 \pm 283,1см3/сек, что значительно превышает аналогичный показатель контрольной группы $(609,0 \pm 55,06$ см3/сек). При этом значение СС было значительно ниже показателя в контрольной группе $(0,15 \pm 0,02$ Па/см3/сек и $0,27 \pm 0,03$ Па/см3/сек соответственно.

Проведение пробы с ФН показало однотипную векторную направленность изменения показателей ПАРМ как у больных с АР, так и у испытуемых контрольной группы.

У больных АР значение СОП незначительно увеличилось после пробы с ФН и составило $1064,0 \pm 306,2$ см3/сек, а СС уменьшилось до $0,14 \pm 0,03$ Па/см3/сек.

Степень изменения показателей была явно ниже, чем в контрольной группе, и составила в абсолютных цифрах для СОП 25,2 $\pm 7.8 \mathrm{~cm} 3 /$ сек, для СС $0,02 \pm 0,01$ Па/см3/сек (в контрольной группе: СОП увеличился на $166 \pm 34,1$ 
см3/сек, СС уменьшилось на 0,079 \pm 0,02 Па/см3/сек). Процентное увеличение СОП составило $2.3 \pm 0,8 \%$, что было значительно ниже контрольной группы, в которой этот показатель был равен $35,7 \pm 9,15 \%$. Падение значения СС в процентном отношении так же значительно отличалось от контрольной группы и составило $6,7 \pm 2,3 \%$ (в контрольной группе - 30,2 $\pm 9,37 \%$ ).

Обращает на себя внимание и форма риноманометрической кривой, полученной при исследовании этой группы больных: кривые значительно отличались от контрольной группы, были приближены к оси ординат, поскольку максимальная разность давления, создаваемая на вдохе, не превышала 150 Па. У большинства больных $\Delta \mathrm{P} 300$ Па не удалось достичь даже при углубленном дыхании.

Таким образом, у больных с атрофическим ринитом методом ПАРМ выявлено существенное увеличение исходного суммарного объемного потока, что связано с патологически широким просветом общих носовых ходов и значительное снижение носового сопротивления, в то время как все больные жаловались на ощущение затруднения носового дыхания. Мы предполагаем, что низкий уровень носового сопротивления у больных с AP оказывается недостаточным для раздражения рецепторов полости носа, участвующих в формировании субъективной оценки свободы носового дыхания, что и создает ощущение «заложенности носа». Физическая нагрузка не вызывает выраженных изменений носового дыхания у больных с вторичным атрофическим ринитом. 


\section{Литература:}

1. Бойко Н.В., Колесников В.Н., Левченко Е.В. Статистика причин затруднения носового дыхания Российская ринология. 2007. № 2. С. 24-25.

2. Бойко Н.В., Колесников В.Н. Клиническая ценность передней активной риноманометрии Российская ринология. 2006. № 3. С. 4-7.

3. Русецкий Ю.Ю., Чернышенко И.О., Попов М.А., Иванов С.Л., Мирошниченко А.П. Состояние дыхательной функции носа при свежих травмах по данным передней активной риноманометрии. Вестник оторинолар. 2007. № 5. С. 29-33.

4. Русецкий Ю.Ю., Соболев В.П., Карапетян Л.С. Объективизация специфических проб для выявления дисфункции носового клапана. Рос. оторинолар. 2014. Т. 72. № 5. С. 57-64. 